\title{
WACANA KEARIFAN LOKAL DALAM PENYELENGGARAAN KEBIJAKAN PEMBANGUNAN PERUMAHAN
}

\author{
Beta Suryokusumo S. \\ Jurusan Arsitektur Fakultas Teknik Universitas Brawijaya \\ Jl. Jl. MT Haryono No. 167 Malang. \\ *Email: betasudarmo@gmail.com; bsudarmo@ub.ac.id
}

\begin{abstract}
ABSTRAK
Perencanaan dan perancangan lingkungan yang berkelanjutan khususnya pembangunan perumahan dan permukiman perlu dikembangkan secara positif dan berkesinambungan. Potensi wacana kearifan lokal yang dapat sinergi didalam tataran hukum positif Kebijakan Pembangunan Perumahan pada UU No.1 tahun 2011, mengenai Perumahan dan Kawasan Permukiman dan UU No.20 tahun 2011 mengenai Rumah Susun dengan kebijakan lain yang mengakomodasi aspek kearifan lokal. Dalam kajian ini dievaluasi kebijakan pembangunan perumahan dan kebijakan tata ruang dan dukungan kebijakan lainnya dalam wacana kearifan lokal. Langkah selanjutnya adalah mengevaluasi hasil survey perumahan pada tiga kegiatan lapangan unutk melihat seberapa jauh aspek kebijakan yang mengakomodasi potensi (kearifan) lokal dengan evaluasi pada studi perubahan ruang dan studi dinamika perubahan rumah pada kawasan perumahan kota di Kota Malang. Dengan metode evaluasi literatur dan empiris serta lapangan, maka padahasil survey menunjukkan bahwa aspek pembangunan perumahan masih bertumpu pada pengembangan (development), lebih dari semangat pembangunan yang berkelanjutan dari yang telah di tetapkan pada perundangan. Aspek potensi (kearifan) lokal, masih belum dimaknai dan menjawab permasalahan dilapangan. Aspek keseimbangan/kesetimbangan yang bertumpu pada Socio-community based, socio-kultural based dan socio ecology based, masih di dominasi aspek socio-economy based. Pembangunan berkelanjutan dapat terarah bilamana keterikatan pada aspek Pembangunan yang bertumpu dan mempunyai keterikatan dengan lingkungan (alam) dan mempertimbangkan nila-nilaii lain (estetika), nilai penghormatan (religius), dan nilai dari kehidupan (eksistensi). Ha-hal ini yang perlu di masukkan dalam kebijakan yang bersifat operasional sebagai bentuk penerapan dan dukungan terhadap potensi, konsepsi (kearifan) lokal.
\end{abstract}

Kata Kunci: Wacana kearifan lokal, kebijakan, perumahan.

\section{PENDAHULUAN}

Pada dasarnya entitas budaya yang sarat akan nilai-nilai sosio, kultural dan ekologis dapat dijadikan "best practice" dalam perancangan lingkungan binaan, melalui penggalian "lesson learnt" yang dikonsepsikan, diaplikasikan, dan diwujudkan pada kebijakan pada wujud rupa lingkungan binaan tradisional maupun modern yang memerlukan 'kearifan' tersendiri dalam pemahamannya (Wikantiyoso, 2009). Latar belakang konsep 'kearifan'-'lokal' harus dilatarbelakangi budaya komunitasnya sebagai sebuah kesatuan hidup (Wikantiyoso, 2009) [1], dan dapat tertanam dan dipahami oleh masyarakatnya atas potensi lokalitasnya secara bijaksana, penuh kearifan, dan bernilai baik. (Antariksa, 2009).
Peluang potensi lokal dapat dijembatani melalui pendekatan partisipatif (community based development; CBD), yang dapat menjembatani pembangunan ekonomi (economy based; EBD) dan keberlanjutan pembangunan (socio-ecological based SEBD) dan mendorong meningkatkan kualitas hidup masyarakat (city of as an engine of economic growth) yang berkeadilan sosial (sosial justice), dalam lingkungan hidup yang lestari (environmental sound) dan berkesinambungan (sustainable sound). (Wikantiyoso, 2009). Namun demikian secara proporsional masih belum mendapat perhatian pada perencanaan komunitas (sosial, budaya) dan perencanaan sumber daya (resources planning) dan masih lebih pada perencanaan fisik dan visual. (Santoso, 2009).

Edisi cetak 
Oleh sebab itu didalam tulisan ini akan di bahas melalui metode evaluasi terhadap literatur yang berkaitan dengan wacana kearifan lokal dan payung kebijakan yang mengakomodasinya dan mengevaluasi hasil survey lapangan pada tiga kegiatan penelitian yang berbeda mengenai studi perumahan di kota Malang. Tujuan dari survey yang berbeda kurun waktu ini untuk melihat apakah kebijakan perumahan sudah diakomodasi dengan mempertimbangkan aspek keseimbangan potensi lokal yang dijembatani dengan pendekatan ditunjang dengan hasil evaluasi pada hasil survey CBD, EBD, dan SEBD tersebut. Hasil pembahasan akan disintesakan untuk melihat sejauh mana wacana kearifan lokal di akomodasi pada kebijakan perumahan dan kawasan permukiman.

\section{PEMBAHASAN}

\section{Kearifan lokal dalam hukum positif}

Secara substansi kearifan lokal dapat berupa aturan mengenai (i) Kelembagaan dan sanksi sosial, (ii) Ketentuan tentang pemanfaatan ruang, dan perkiraan musim untuk bercocok tanam, (iii) Pelestarian dan perlindungan terhadap kawasan sensitif serta (iv) Bentuk adaptasi dan mitigasi tempat tinggal terhadap. Keberlanjutan, mitigasi bencana. (Santoso, 2009) [3]. Potensi tersebut telah tertuang pada perundangan di UU No. 26 Tahun 2007 tentang Penataan Ruang yang mengatur penetapan kawasan strategis dari sudut kepentingan sosial, budaya, baik pada tingkatan Nasional/Propinsi sampai dengan Kabupaten/Kota. Juga masuk dalam UU No. 32 Tahun 2009 tetang Perlindungan dan Pengelolaan Lingkungan Hidup dimana harus tetap memperhatikan nilai-nilai agama, adat istiadat, dan nilai-nilai hidup dalam masyarakat.

Sedangkan pada UU no 11 Tahun 2010 tentang Cagar Budaya, mengatur bahwa perlindungan dan pelestarian benda cagar budaya harus dilakukan secara optimal melalui perlindungan terhadap nilai-nilai budaya tradisional yang sarat dengan kearifan lokal. Potensi ini juga masuk di dalam UU No. 28 Tahun 2002 tentang Bangunan Gedung yang mengatur tentang perlunya perlindungan terhadap bangunan yang memiliki nilai sejarah dan persyaratan untuk mengakomodasi dan mempertimbangkan nilai-nilai sosial dan budaya setempat dalam pengembangan atau pemeliharaan arsitektur gedung dan bangunan bersejarah. Pada beberapa produk perundangan lainnya, potensi kearifan lokal masuk didalam konteks perlindungan terhadap sumber daya air, yaitu UU No. 7 Tahun 2004 tentang Sumber Daya Air yang mengatur tentang pelestarian kawasan irigasi yang memiliki kearifan lokal. Selain itu juga dalam UU No. 37 Tahun 2002 tentang Pengelolaan Wilayah Pesisir dan Pulau Kecil juga telah mengakomodasi Hak Ulayat khususnya dalam kebijakan Hak Pengusahaan Pengairan.

Lebih jauh lagi dalam konteks pembangunn perumahan dan pengembangan permukiman yaitu UU No. 1 tahun 2011 tentang Perumahan dan Kawasan Permukiman dan UU No. 20 2011, tentang Rumah Susun, wacana kearifan lokal telah terdefinisikan pada satu pengertian yaitu, tempat tinggal (hunian) atau lingkungan harian yang dilengkapi dengan prasarana dan sarana lingkungan, yang bukan sekedar tempat berlindung tetapi merupakan produk budaya, dimana nilai norma dan tradisi berpengaruh lebih dalam bentuk kekayaan. (Kallo, Erwin, 2009). Sebagai Landasan operasionalnya diterapkan pada Peraturan Pemerintah No. 88 Tahun 2014 tentang Pembinaan Penyelenggaraan Perumahan dan kawasan pada tingkat pemerintahan daerah. Selain itu berdasarkan PP No. 10 Tahun 2012 [14] tentang Penyelenggaraan Perumahan dan Kawasan Pemukiman dan Hunian berimbang, pada Pasal 1 ayat (2) dimaksudkan dengan rumah adalah bangunan gedung yang berfungsi sebagai tempat tinggal layak huni sarana pembinaan keluarga, cerminan harkat dan martabat penghuninya, serta aset bagi pemiliknya. Sedang pada Perda No. 23 Tahun 2014 [15] Pemerintah Daerah, mengenai Urusan Wajib dan Pelayanan Dasar dalam Pasal 11, ayat 2 bagian (d) Perumahan Rakyat dan Kawasan Pemukiman tupoksinya sama dengan Pasal 12 di UU No. 1 Tahun 2011 [4] pada penyelenggaraan perumahan sebagaimana dimaksud dalam Pasal 19, bagian (b) Pembangunan Perumahan dikembangkan Berdasarkan tipologi kearifan lokal.

Sedangkan pada pada UU No. 1 tahun 2011 mengenai Perumahan dan Kawasan Permukiman, menegaskan pengembangan rumah yang layak, terjangkau dan berkelanjutan yang tercantum pada bagian pertimbangan (e). Pertimbangan asas keseimbangan menjadi kunci pengembangan Undang Undang ini. Secara tersirat aspek kearifan lokal terdapat pada pasal 2 bagian (k) dan pasal 3 bagian (c), aspek 
kelestarian dan keberlanjutan dijadikan azas penyelenggaraan perumahan. Peran serta masyarakat dilibatkan sebagai bagian potensi lokal yang terdapat pada pasal 7 ayat 2 . Sedangkan pada pasal 15 ayat (e), dan pasal 16 ayat (f), dan pasal 17 ayat (f) Pemerintah kabupaten/kota dan pemerintahan pusat, dan pemerintah provinsi dalam melaksanakan pembinaan mempunyai tugas: melaksanakan pemanfaatan teknologi dan rancang bangun yang ramah lingkungan serta pemanfaatan industri bahan bangunan yang mengutamakan sumber daya dalam negeri dan kearifan lokal yang aman bagi kesehatan. Sedangkan pada pasal 18 ayat (b), pemerintah Kabupaten/Kota mempunyai kewenangan menyusun dan menyempurnakan peraturan perundang undangan bidang perumahan dan kawasan permukiman pada tingkat kabupaten/kota bersama DPRD.

\section{Keseimbangan dalam pembangunan perumahan}

Secara hakekat tujuan perundangan penataan ruang dan perundangan perumahan dan permukiman adalah untuk mencapai azas keseimbangan yang ingin dicapai dengan sembilan aspek yang tercantum dalam azas penyelenggaraan penataaan ruang. Sedangkan tujuan menurut pasal 26 ayat (1), Hasil perencanaan dan perancangan rumah harus memenuhi persyaratan teknis, administratif, tata ruang, dan ekologis. Begitupun pasal 29 ayat (1), sedangkan pada pasal 32 pembangunan perumahan ayat (2), Pembangunan perumahan dilakukan dengan mengembangkan teknologi dan rancang bangun yang ramah lingkungan serta mengembangkan industri bahan bangunan yang mengutamakan pemanfaatan sumber daya dalam negeri dan kearifan lokal yang aman bagi kesehatan.

Pada pasal 38 ayat 2, Pembangunan rumah sebagaimana dimaksud pada ayat (1) dikembangkan berdasarkan tipologi, ekologi, budaya, dinamika ekonomi pada tiap daerah, serta mempertimbangkan faktor keselamatan dan keamanan. Ayat 1 (Pembangunan rumah meliputi pembangunan rumah tunggal, rumah deret, dan/atau rumah susun.). pada pasal 56 ayat (1), mengenai penyelenggaraan perumahan dan kawasan permukiman dilakukan untuk mewujudkan wilayah yang berfungsi sebagai lingkungan hunian dan tempat kegiatan yang mendukung peri-kehidupan dan penghidupan dengan azas keseimbangan yang terencana, menyeluruh, terpadu, dan berkelanjutan sesuai dengan rencana tata ruang yang dimaksud untuk melengkapi potensi lokal tersebut. Pada pasal 96, strategi sosio-budaya diakomodasi masuk dalam pasal upaya peningkatan kualitas terhadap perumahan kumuh dan permukiman kumuh, Pemerintah dan/atau pemerintah daerah menetapkan kebijakan, strategi, serta pola-pola penanganan yang manusiawi, berbudaya, berkeadilan, dan ekonomis. Pasal 97 ayat (1) Peningkatan kualitas terhadap perumahan kumuh dan permukiman kumuh sebagaimana dimaksud dalam Pasal 96 didahului dengan penetapan lokasi perumahan kumuh dan permukiman kumuh dengan pola-pola penanganan: (a). Pemugaran; (b). Peremajaan; atau (c). Pemukiman kembali. Aspek Peran serta masyarakat dimasukkan pada Pasal 131 ayat (1) Penyelenggaraan perumahan dan kawasan permukiman dilakukan oleh Pemerintah dan pemerintah daerah dengan melibatkan peran masyarakat. Pada ayat (2) Peran masyarakat sebagaimana dimaksud pada ayat (1) dilakukan dengan memberikan masukan dalam: (a). Penyusunan rencana pembangunan perumahan dan kawasan permukiman; (b). Pelaksanaan pembangunan perumahan dan kawasan permukiman; (c). Pemanfaatan perumahan dan kawasan permukiman; (d). Pemeliharaan dan perbaikan perumahan dan kawasan permukiman; dan/atau (e). Pengendalian penyelenggaraan perumahan dan kawasan permukiman; sedangkan pada ayat (3) Peran masyarakat sebagaimana dimaksud pada ayat (2) dilakukan dengan membentuk forum pengembangan perumahan dan kawasan permukiman. Dapat disimpulkan bahwa aspek EBD, SEBD, dan CBD coba diakomodasikan untuk mendapatkan 'equilibrium', dalam penyelenggaran pembangunan perumahan berkelanjutan.

\section{Evaluasi terhadap survey perumahan}

Survey perumahan dilakukan untuk melihat tingkat perubahan pada rumah yang dilakukan oleh penghuni didalam menempati rumah tersebut dalam perkembangan sejak mereka menempati rumah tersebut. Tipe rumah yang disurvey berkisar dari dan $36 \mathrm{~m}^{2}, 45 \mathrm{~m}^{2}$, $54 \mathrm{~m}^{2}$ tipe, dan tipe $60 \mathrm{~m}^{2}$, yang dilakukan pada lokasi yang berbeda. Jumlah rumah yang dijadikan pada ketiga penelitian tersebut adalah 60 buah rumah. Tujuan dari survey ini adalah 
untuk melihat tingkat perubahan rumah dan sikap penghuni terhadap rumahnya terhadap perubahan rumah. Hasil dari survey pertama pada tipe $36 \mathrm{~m}^{2}$ dan tipe $45 \mathrm{~m}^{2}$, pada aspek sosial budaya, keluarga inti $62 \%$ (suami, istri, anak), $25 \%$ keluarga tambahan, 10\% adalah suami, istri, dan $3 \%$ adalah lajang. Jumlah anggota keluarga pada saat menempati 1 orang $5 \%$ ), 2 orang (15\%), 3 orang (35\%), 4 orang $(23 \%)$, dan lebih dari 4 orang (22\%). Ditinjau dari pendidikan kepala keluarga, maka sampel terpilih dapat dikatakan mempunyai tingkat pendidikan yang cukup baik. Sebagian besar atau 59\% sampel mempunyai pendidikan lebih dari SMA. Sebanyak 34\% sampel, pendidikan kepala keluarga adalah SMA dan selebihnya SMP sebanyak 5\% dan SD 2\%. Berdasarkan hasil survei diketahui bahwa pekerjaan sampel terdiri atas 23\% Wiraswasta, 22\% Karyawan Swasta, 21\% Pensiunan dan 18\% PNS. Selebihnya adalah Karyawan BUMN 7\%, lainlain 7\% dan TNI/ POLRI 2\%. Dari hasil survei diketahui bahwa $64 \%$ istri dari responden bekerja dan sisanya $36 \%$ tidak bekerja. Pekerjaan mereka terdiri atas, $21 \%$ karyawan swasta, 20\% wiraswasta dan $14 \%$ PNS. Selebihnya adalah pensiunan $5 \%$ dan lainlainnya $4 \%$. Sebagian besar sampel, $70 \%$ tidak mempunyai usaha sampingan di rumah 9\% mempunyai usaha toko kelontong, 5\% warung dan salon serta fotokopi masing masing $2 \%$, $12 \%$ sisanya sampel membuka usaha sampingan berupa usaha lain lain seperti praktek dokter dan lainnya. Dinamika perubahan ruang dan tampilan pada rumah merupakan inti dari permasalahan penelitian ini. Hampir sebagian besar sampel, $71 \%$ melakukan perubahan rumah-rumah mereka. Sebanyak 25\% lainnya hanya melakukan perubahan ruang dan hanya 4\% yang melakukan perubahan tampilan saja pada rumah mereka. Alasan perumahan rumah pada sampel lebih banyak disebabkan karena responden merasa kondisi fisik rumah perlu diperbaiki, mencapai 48\%. Alasan terbanyak kedua sebanyak 19\% adalah karena membuka usaha sampingan di rumah. Penambahan anggota keluarga dan penambahan perabot merupakan alasan selanjutnya dengan jumlah masing-masing sebanyak $13 \%$. Hanya $7 \%$ sampel yang menyebutkan pertambahan penghasilan sebagai alasan perubahan rumah mereka. Pada umumnya perubahan rumah dilakukan sebelum tahun ke-5 sejak dihuni bahkan $35 \%$ sampel melakukan perubahan sebelum ditempati. Sebanyak 34\% sampel melakukan perubahan pada tahun ke 2 sampai tahun ke 5. Sedangkan 20\% sampel melakukan perubahan rumahnya pada tahun pertama sampai tahun ke 2. Sampel yang melakukan perubahan setelah tahun ke 5 hanya sebesar $11 \%$.

Berdasarkan data hasil survei diketahui bahwa perubahan ruang yang dilakukan meliputi penambahan ruang $38 \%$, perluasan ruang $27 \%$, perubahan tata letak $21 \%$, dan perubahan total 14\%. Dari data tersebut dapat diketahui bahwa jumlah ruang pada rumah sederhana dirasakan kurang oleh para penghuni sehingga mereka melakukan penambahan jumlah ruang sesuai dengan kebutuhan mereka. Perluasan ruang pada rumah sampel tidak terdapat pada ruang tidur dan dapur merupakan ruang yang luasnya relatif tetap masing-masing sebesar $75 \%$ dan $68 \%$ dari jumlah sampel. Sedangkan ruang makan dan ruang keluarga yang mengalami perluasan adalah lebih dari separuh yang masing-masing sebanyak 57\% dan 52\% dari jumlah sampel. Berdasarkan data bahwa luas ruang makan dan ruang keluarga yang terdapat pada rumah sederhana memang dirasakan kurang. Hal ini dapat dipahami mengingat bahwa ruang makan dan ruang keluarga dapat dikatakan bukan merupakan ruang-ruang utama yang diprioritaskan. Hampir seluruh rumah ruang pada rumah-rumah sampel tidak mengalami penambahan ruang. Dari hasil survei kuesioner diketahui bahwa hanya ruang tamu yang mengalami penambahan yaitu sebanyak 9\% dari jumlah sampel.

Pada kategori tampilan rumah, maka jenis perubahan yang dilakukan lebih banyak dilakukan pada perubahan bentuk pintu dan jendela, yaitu sebanyak 39\%. Perubahan tampak bangunan secara total juga banyak dilakukan oleh $26 \%$ responden. Dalam hal pergantian bahan bangunan, dilakukan oleh $23 \%$ responden. Jenis pergantian bahan bangunan ini misalnya penggantian jenis genteng, penutup lantai, pelapis dinding, jenis kaca, dan jendela. Penggantian bentuk atap merupakan jenis perubahan yang dilakukan oleh $12 \%$ saja. Dari deskripsi di atas, dapat dilihat kecenderungan penghuni untuk lebih memfokuskan perubahan pintu dan jendela pada rumah mereka. Secara garis besar, rumah yang telah mengalami perbaikan menunjukkan tingkat kenyamanan yang positif. Sebanyak $75 \%$ diantaranya memiliki rasa nyaman pada rumah yang telah diperbaiki. Perasaan sangat nyaman ditunjukkan $16 \%$ responden, dan yang merasa sudah cukup 
nyaman hanya $9 \%$ saja. Perasaan tidak nyaman dan sangat tidak nyaman tidak ditunjukkan oleh para responden. Kecenderungan yang muncul pada aspek ini adalah meningkatnya rasa nyaman yang dialami oleh para penghuni rumah setelah mereka melakukan perbaikan pada tempat tinggal mereka. Dalam hal kualitas pencahayaan, peningkatan positif juga ditunjukkan oleh para responden. Sebanyak $79 \%$ responden menyatakan kualitas pencahayaan setelah diperbaiki memiliki tingkatan yang baik, sisanya sebanyak $21 \%$ responden menyatakan kualitas tingkat sedang. Tidak ada responden yang merasakan kurang pencahayaan pada rumah mereka yang telah diperbaiki. Kecenderungan yang muncul pada aspek ini adalah meningkatnya persepsi positif yang dialami oleh para penghuni setelah mereka melakukan perbaikan pada tempat tinggal mereka. Kualitas penghawaan yang baik juga dirasakan oleh para responden setelah mengalami perbaikan rumah, yaitu sebesar $80 \%$. Kualitas sedang $16 \%$ dirasakan oleh sebagian kecil, dan hanya $4 \%$ saja yang merasa kurang dalam hal penghawaan. Dari deskripsi tersebut dapat diartikan bahwa responden memiliki kecenderungan untuk merasakan penghawaan yang lebih baik setelah rumahnya diperbaiki. Dalam hal susunan dan tata letak ruang atau kamar setelah yang diperbaiki menunjukkan persepsi positif dikalangan responden. Sebanyak $77 \%$ memiliki persepsi baik dan $23 \%$ memiliki persepsi sedang. Tidak adanya persepsi kurang (sebesar 0\%) memperkuat kecendrungan peningkatan positif kualitas tata ruang/kamar pada rumah-rumah yang telah diperbaiki. Data tersebut menunjukkan bahwa kualitas fisik pada rumahrumah sederhana yang belum memenuhi syarat maupun keinginan penghuni. Pada survey kedua, dengan sampel studi 30 buah rumah, maka diketahui Kemampuan untuk merubah realitas fisik adalah suatu kekuatan. Kemampuan disini adalah kemampuan secara finansial dan ekonomis dalam mengelola keuangannya untuk melakukan perubahan pada rumahnya. Hal ini terlihat dari tingkat pendapatan pada kasus studi berkisar pada kisaran Rp. 1.000.0000,- s/d 3.000.000,- sebesar $36.6 \%$ dan tingkat pendapatan sebesar $\mathrm{Rp}$. $3.000 .000 \mathrm{~s} / \mathrm{d}$ Rp 5.000.0000,- berkisar 36.6\%. dilihat dari segi pandapatan tersebut penghuni rumah memiliki kemampuan dalam mengintervensi rumahnya. Hal ini juga ditunjang sebanyak $20 \%$ istri dari kepala rumah tangga bekerja sebagai karyawan swasta. Tingkat perubahan dari segi rancangan ruang yang ada pada tingkat perubahan dari tipe awal hunian dasar seluas $36 \mathrm{~m}^{2}, 45 \mathrm{~m}^{2}$ dan $54 \mathrm{~m}^{2}$.

Sedangkan proses perubahan bentuk rumah pada studi kasus terlihat mengalami proses sebagai berikut: Pertama, Ekspansi/ tumbuh, artinya mengadakan perluasan keluar (perluasan $35 \%$ dan penambahan $48 \%$ ), kedua sub-divisi, artinya mengadakan perbanyakan ruang melalui pembagian didalam (tanpa mengubah bahan) misalnya menyekat ruang. Pada kasus tidak terdapat prosentase untuk subdivisi, yang ketiga penyempurnaan, artinya perubahan berkaitan dengan Peningkatan kenyamanan, seperti penggantian bahan, modifikasi ruang dan lainnya (75\% responden). Sedangkan proses perbaikan terdapat $48 \%$ responden melakukannya pada rumah melalui tahap awal Perombakan rumah, artinya perubahan struktur fisik rumah secara total (perubahan bentuk, bahan, jumlah ruang, ukuran ruang dan lainnya). Tahap kedua Pergantian bahan secara menyeluruh (lantai, dinding dan atap) tanpa mengubah jenis dan jumlah elemen rumah, luas rumah,jumlah ruang dan bentuk. Tahap ketiga Pergantian bahan sebagian pada elemen rumah, tanpa mengubah jenis dan jumlahnya. Tahap keempat hubungan antara "setting", ruang dan perilaku. Dalam kaitannya dengan manusia, hal paling penting dari pengaruh ruang terhadap perilaku manusia adalah fungsi pemakaian dari ruang tersebut. Pada rumah sederhana seringkali terdapat ruang bersama yang berfungsi sebagai ruang tamu, ruang keluarga/ruang santai dan ruang makan seiring dengan tingkat kemampuan perilaku pengguna menyebabkan kebutuhan akan ruangruang khusus yang dapat sebagai tempat melakukan kegiatan sesuai dengan kegiatan dan perilaku pengguna. Oleh sebab itu dalam merancang terdapat dua macam ruang yang dapat mempengaruhi perilaku. Pertama, ruang yang dirancang untuk memenuhi suatu fungsi dan tujuan tertentu. Kedua, ruang yang dirancang untuk memenuhi fungsi yang lebih fleksibel. Dari uraian diatas kebutuhan akan ruang makan $36.7 \%$ dan kebutuhan akan ruang kelaurga $46.7 \%$ menjadi mengemuka seiring dengan tingkat kemampuan dan pengetahuan masing-masing manusia. Dari hasil kajian terhadap rancangan awal berupa denah pada rumah tinggal sederhana tipe 36 terdapat sampel 
sejumlah 32 sampel yang dapat dikaji. Data awal rumah terdapat ruang serbaguna yang berfungsi sebagai ruang tamu, ruang keluarga dan ruang makan sebesar $12 \mathrm{~m}^{2}$, ruang tidur sebesar $18 \mathrm{~m}^{2}$ (dua kamar tidur), ruang dapur 3 $\mathrm{m}^{2}$ dan kamar mandi (WC) $3 \mathrm{~m}^{2}$. Hasil kajian berdasarkan rata-rata kecenderungan sampel yang muncul, ternyata terdapat penambahan jenis ruang berdasarkan faktor-faktor yang telah diuraikan diatas seperti, terdapat ruang tamu sebesar $11 \mathrm{~m}^{2}$, ruang keluarga sebesar $13 \mathrm{~m}^{2}$, ruang makan sebesar $9 \mathrm{~m}^{2}$, ruang tidur sebesar $24 \mathrm{~m}^{2}$, ruang dapur sebesar $6 \mathrm{~m}^{2}$ dan kamar mandi sebesar $5 \mathrm{~m}^{2}$ jumlah besaran ruang yang muncul untuk rancangan rumah sederhana adalah sebesar $68 \mathrm{~m}^{2}$, didasarkan pada kemajuan ekonomi, kebutuhan akan keluarga baru, kemajuan tingkat kepentingan ruang. Dari hasil pengolahan data diatas terlihat bahwa untuk tipe $36 \mathrm{~m}^{2}$ terdapat kecenderungan dari penghuni rumah untuk menambah ruang serba guna dengan membagi ruang (sub-division) dan menambah (addition) luas ruang dengan ruang tamu menjadi dua kali luasan asal $6 \mathrm{~m}^{2}$ menjadi $11 \mathrm{~m}^{2}$. Penambahan ruang tamu mempunyai konsekuensi untuk mempolakan hubungan yang erat antara ruang makan dan ruang keluarga sebagai tempat yang paling dominan dalam beraktivitas. Penambahan ukuran ruang keluarga menjadi dominan yaitu dengan luasan yang lebih besar dari ruang tamu dan berfungsi lebih khusus dalam penataan ruang. Penambahan ini juga dipengaruhi oleh faktor budaya dan lingkungan dimana keberadaan ruang keluarga seringkali menjadi pusat aktivitas sebagian anggota keluarga dalam satu hari kegiatan. Adanya penetapan ruang keluarga memberikan kesempatan kepada ruang makan menjadi leluasa dan dipisah, dengan penambahan luasan agar kenyamanan pada saat berkumpul dimeja makan dapat terpenuhi. Kebutuhan luasan ruang makan untuk empat sampai dengan enam orang adalah berkisar 9 meter persegi. Kebutuhan akan ruang tidur menjadi penting manakala terjadi penambahan anggota keluarga baru, seperti adanya anak kedua, atau adanya pembantu yang menunjang kegiatan dirumah. Penambahan ruang tidur yang minimum adalah berkisar enam meter persegi atau dua kali tiga meter persegi. Pembesaran ruang terjadi pada ruang dapur dan kamar mandi dengan ukuran awal minimum sebesar tiga meter persegi menyebabkan kesulitan anggota keluarga dalam melakukan aktivitas memasak dan mandi. Oleh sebab itu perluasan menjadi lima sampai dengan enam meter persegi memberikan kecukupan ruang pada penghuninya.

Untuk tipe $45 \mathrm{~m}^{2}$ dan tipe $54 \mathrm{~m}^{2}$ dari hasil pembahasan diatas terlihat bahwa terjadi perubahan ruang berupa penambahan (addition) dan pembagian (sub division dengan penambahan (sub-division with addition) yang terlihat pada uraian sebagai berikut: Untuk ruang tamu pada tipe 45 terlihat perubahan ukuran ruang dari $6 \mathrm{~m}^{2}$ menjadi $12 \mathrm{~m}^{2}$. untuk tipe $54 \mathrm{~m}^{2}$ terlihat dari ukuran $12 \mathrm{~m}^{2}$ menjadi 10 $\mathrm{m}^{2}$. Hal ini menandakan bahwa kecukupan sebuah ruang tamu sebesar $6 \mathrm{~m}^{2}$ dirasa sangat kurang sekali sedangkan ukuran $12 \mathrm{~m}^{2}$ dirasa berlebihan dari unsur kecukupan ruang. Oleh sebab itu dari hasil penelitian unsur kecukupan ruang dengan rata-rata perhitungan adalah dengan $10 \mathrm{~m}^{2}$. Untuk ruang serbaguna (ruang dengan aktivitas campuran) kejelasan akan sebuah ruang menjadi penting hal ini untuk menandakan bahwa adanya ruang keluarga dan ruang makan yang terpisah tetapi masih menyatu dengan luasan masing-masing menjadi penting agar komposisi ruang rumah yang terbentuk sama atau setara dengan ruang-ruang pada rumah-rumah lainnya dalam lingkungan tersebut. Ukuran ruang keluarga pada kedua tipe awal berkisar antara $12 \mathrm{~m}^{2}$ sampai dengan 15 $\mathrm{m}^{2}$. dengan adanya perubahan pada luasan ruang keluarga, maka luasan yang terbentuk dari hasil pembahasan adalah $18 \mathrm{~m}^{2}$. temuan $18 \mathrm{~m}^{2}$ ini menandakan bahwa ruang keluarga yang memenuhi rasa cukup adalah pada ukuran tersebut. Untuk ruang makan dari hasil pembahasan terlihat bahwa ukuran data awal ruang serbaguna yang berkisar antara $12 \mathrm{~m}^{2}$ sampai $15 \mathrm{~m}^{2}$, untuk ukuran ruang makan yang memenuhi rasa kecukupan adalah $9 \mathrm{~m}^{2}$ sampai $10 \mathrm{~m}^{2}$. Pemenuhan akan ruang tidur pada tipe 45 dan tipe 54 menjadi bertambah bila mana terdapat anggota keluarga baru yang memerlukan ruang tersendiri. Pada kedua tipe awal luasan kamar tidur untuk dua kamar adalah sebesar $18 \mathrm{~m}^{2}$. dari hasil pembahasan terlihat adanya kesamaan pada tipe 54 dan 45 mengenai jumlah kamar tidur menjadi 3 buah dan luasan total tiga kamar tersebut menjadi $27 \mathrm{~m}^{2}$, atau rata-rata per kamar tidur berkisar $9 \mathrm{~m}^{2}$. Untuk kebutuhan kamar mandi dari data awal terlihat bahwa ukuran berkisar antara $3 \mathrm{~m}^{2}$ sampai dengan $4 \mathrm{~m}^{2}$. dari hasil pembahasan pada dua tipe rumah ternyata ukuran kamar mandi yang cukup bagi penghuni sebesar $5 \mathrm{~m}^{2}$. ukuran tersebut bisa menjadi dua buah kamar mandi berukuran $3 \mathrm{~m}^{2}$ dan $2 \mathrm{~m}^{2}$. 
Pada survey lanjutan ketiga, pada tipe $54 \mathrm{~m}^{2}$ dan tipe $60 \mathrm{~m}^{2}$, dari 30 sampel rumah, $62 \%$ melakukan perubahan rumah karena kebutuhan penambahan ruang, perubahan ruang, dan perubahan fungsi menjadi unit usaha rumah. $38 \%$ disebabkan pergeseran selera (minat), atas estetika, visual, proporsi dari rumah yang dipengaruhi faktor trend. Alasan memilih lokasi dan kenyamanan menempati $32 \%$, suasana $23 \%$, harga $9 \%$ dan tipe $4 \%$. Tampilan $0 \%$. Perubahan tampilan dilakukan setelah membeli $67 \%$ dan setelah lama menempati (lebih dari 5 tahun) sebesar 33\%. Perubahan fisik pada rumah disebabkan aspek kemampuan ekonomi (menengah), dan kemampuan untuk menyesuaikan estetika, visual terhadap kemampuan ekonomi dari penghuni.

\section{KESIMPULAN}

Bila dilihat hasil survey pada perumahan sederhana dan menengah untuk memperoleh gambaran mengenai aspek kebijakan pemabangunan perumahan dan permukiman yang mengakomodasi aspek potensi lokal (kearifan lokal) dalam mengimplementasikan perundangan yang telah dijelaskan diatas. Dapat disimpulkan pemenuhan pemerintah dalam berupaya memenuhi amanat undang-undang masih pada tataran pembangunan dan pengembangan fisik untuk memenuhi kebutuhan dasar masyarakatnya (manusia), aspek keseimbangan/kesetimbangan 'equilibrium' telah ditetapkan pada perundangan yang terbaru pada penataan ruang, perumahan dan kawasan permukiman, dan perundangan rumah susun. Operasionalisasi kebijakan dengan Peraturan Pemerintah dan Perda masih terbatas pada tataran filosofis, dan normatif. Ini terlihat dari aspek potensi (kearifan) lokal, belum terlihat pada situasi lokalitas masyarakat yang menempati hunian (perubahan ruang, perluasan ruang bersama, sebagai aspek keluarga (guyub, rukun)), masih belum di wadahi. Pemenuhan rumah masih lebih ditekankan pada aspek kuantitatif (jumlah rumah yang dapat dibangun), dengan merujuk pada nilai satuan luasan tertentu. Pada UU No 1, tahun 2011, potensi kearifan lokal ditekankan pada penggunaan sumber daya lokal dan tipolgi kearifan lokal yang berbeda dari sekedar pembangunan berdasarkan pada pemenuhan komoditas kebutuhan dan kuantitas fisik rumah bagi masyarakat.
Dapat disimpulkan hasil survey tersebut dalam hubungan dengan penerapan kebijakan yang mengakomodasi potensi lokal bahwa bahwa terdapat permasalahan yang dapat dijadikan wacana bagaiamana potensi (kearifan) lokal merupakan bagian penting pada pengembangan perumahan, yaitu:

Aspek Sosio-fisiologi, kenyamanan ruang (klimat), suasana (rasa), menjadi satu permasalahan pada pembangunan perumahan. Aspek potensi lokal arsitektur (hunian tropis lembab) yang adapatif (socio-ekologis) dapat digunakan untuk menyelesaikan permasalahan ini.

1. Aspek Sosio-psikologi, yaitu penambahan anggota baru (anak) menjadi satu budaya yang dimiliki di Indonesia. Hal ini menyebabkan terjadinya pergeseran ruang, perubahan, dan penambahan ruang yang dapat memenuhi anggota keluarga tersebut.

2. Aspek Sosio-Budaya, kebiasaan, berkumpul dalam keluarga, suasana guyub, rukun dalam satu keluarga juga memerlukan perubahan, penambahan ruang tersebut.

3. Aspek Sosio-Ekonomi, perubahan rumah seringkali disebabkan adanya perubahan rumah menjadi unit usaha yang meningkatkan taraf hidup keluarga dan sebagai usaha sampingan.

4. Aspek Sosio-Ekologi, yaitu perubahan rumah juga menyebabkan pertambahan energy dalam membangun (renovasi/retrofit). Energi kemampuan rumah tangga juga akan memberi dampak pada sistem keberlanjutan rumah tangga dan ini menjadi satu permasalahan yang sering terjadi.

5. Aspek Sosio-Partisipasi masyarakat (SocioCommunity Based Development; SCoBD), yang masih tetap belum mendorong masyarakat terlibat didalam kegiatan perencanaan pembangunan perumahan yang melengkapi peran mengelola lingkungan dan mendorong rumah yang dapat memenuhi aspek kesinambungan/ keberlanjutan (Socio-Ecology Based Development; SEcologyBD), yang berbudaya (Socio-Cultural Based development; $S C \mathrm{CuD}$ ) yang berimbang/ setimbang (equilibrium) dengan (SocioEconomy Based Development; SEconomyBD). 


\section{PENUTUP}

Revitalisasi kebijakan pembangunan perumahan yang berkelanjutan dalam wacana potensi (kearifan) lokal dapat diperluas lebih dari tiga aspek yang ada mengenai kebijakan pembangunan yang bertumpu pada aspek ekonomi, sosial-budaya, dan lingkungan (Keraf, 2001:2) yang holistik integratif (Purnomo, 2013). Agar kesinambungan bisa berjalan sebaiknya dapat memenuhi: (1) pembangunan berkelanjutan tetap bertumpu pada alam (ekologi); (2) Pembangunan yang tidak hanya berpandangan pada alam sebagai sekedar alat pemenuhan kebutuhan material manusia; (3) Pembangunan juga harus melihat daya dukung lingkungan dan toleransinya pada ekosistem. (Keraf, 2001:15); (4) Pembangunan yang bertumpu keterikatan dengan lingkungan dan mempertimbangkan nilai-nilai lain (estetika), nilai penghormatan (religius), dan nilai dari kehidupan (eksistensi) (Purnomo, 2013).

\section{Daftar Pustaka}

Antariksa, (2009) Kearifan Lokal dalam Arsitektur perkotaan dan Lingkungan Binaan.Malang Group Konservasi dan Arsitektur Kota, Malang. ISBN 979-9799488-43-5. Hal 32.

Kallo, Erwin (2009) Perspektif Hukum dalam Dunia Properti, Minerva Athena. Pressindo, Jakarta. Hal 14-15.

Keraf, Sonny, (2001) Pembangunan Berkelanjutan Atau Berkelanjutan Ekologi, dalam Hukum dan Lingkungan Hidup Indonesia, Universitas Indonesia, Jakarta. Hal 2; 15.

UU No. 1, Tahun 2011, Perumahan dan Kawasan Permukiman.

UU No. 32. Tahun 2009, Perlindungan dan Pengelollan Lingkungan Hidup.

UU No. 11 Tahun 2010, Cagar Budaya.

UU No. 28. Tahun 2002, Bangunan Gedung.

UU No. 7 tahun 2004, Sumber Daya Alam.
UU No. 37 Tahun 2002, Pengelollan Wilayah Pesisir.

UU No. 26 Tahun 2007, Penataan Ruang.

UU No. 20, Tahun 2011, Rumah Susun.

Wikantiyoso, Respati \& Tutuko, Pindo (2009) Prawacana, Local Wisdom: Kearifan Lokal dalam Perencanaan dan Perancangan Kota untuk mewujudkan arsitektur yang berkelanjutan. Malang Group Konservasi dan Arsitektur Kota, Malang. ISBN 979-979-9488-43-5. Prawacana hal 2.

PP No. 88 Tahun 2014, Pembinaan Penyelenggaraaan Perumahan dan Kawasan Permukiman.

PP No. 10 Tahun 2012, Penyelenggaraaan Perumahan dan Kawasan Permukiman.

Perda No.23 Tahun 2014 Mengenai Urusan Wajib dan Pelayanan Dasar.

Santoso, Iman (2009) Kearifan lokal dalam perspektif penataan Ruang. Malang Group Konservasi dan Arsitektur Kota, Malang. ISBN 979-979-9488-43-5.

Purnomo, Daru (2013) Ekofilosofi "Deep Ecology", Menggugat Paradigma Pembangunan, Jurnal Ilmu Pendidikan, Sejarah dan Sosial Budaya. Volume 10, No3. Widya Sari Press., ISSN 1412-8985. 